\title{
Polszczyzna bydgoszczan. Historia i wspótczesność, red. M. Święcicka, Bydgoszcz 2003, s. 274
}

Po Warszawie, Krakowie, Łodzi, Katowicach, Wrocławiu i Poznaniu do grona polskich miast, których mowie poświęcono nie pojedyncze szkice (jak ma to miejsce na przykład w wypadku Białegostoku), lecz obszerny tom studiów językoznawczych, dołączyła Bydgoszcz. Różnorodnym aspektom funkcjonowania polszczyzny $w$ warunkach bydgoskich poświęcony jest tom Polszczyzna bydgoszczan, który podtytułem Historia $i$ wspótczesność informuje, że ujęte w nim opracowania traktują nie tylko o współczesnym wymiarze i funkcjonowaniu mowy bydgoszczan, ale - choć w znacznie mniejszym wymiarze - także jej dalszej i bliższej przeszłości.

Ujęcie w syntetyczną i zwartą całość kilkunastu studiów, różnych nie tylko co do treści, ale i pod względem stosowanych rozwiązań metodologicznych, to niewątpliwie zasługa redaktora tomu, nie zupełnego nowicjusza w dziedzinie prac nad językiem miasta, lecz doświadczonego już językoznawcy bydgoskiego, mianowicie Małgorzaty Swięcickiej, która na nowym materiale językowym wykorzystała doświadczenia zdobyte podczas pracy pod kierunkiem Moniki Gruchmanowej nad mową mieszkańców Poznania ${ }^{1}$.

Polszczyznę bydgoszczan otwiera historyczny szkic Franciszka Mincera ukazujący rozwój Bydgoszczy (prawa miejskie w 1346) od jego początków na przełomie X/XI wieku, przez okres świetności (druga połowa XV i cały wiek XVI), aż po współczesność, z podkreśleniem wieków upadku miasta oraz trudnych lat zaborów i okupacji, które pozostawiły w języku miasta i jego warstwie onomastycznej liczne i rozległe ślady.

1 Por. M. Gruchmanowa, M. Witaszek-Samborska, M. Żak-Swięcicka, Mozva mieszkańcótu Poznunia, Poznań 1986. 
Na pozostałą część książki składa się czternaście studiów już ściśle językoznawczych podejmujących różnorodną problematykę z zakresu kształtu i funkcjonowania polszczyzny bydgoskiej, co znajduje odzwierciedlenie w układzie opracowań w sześć kręgów tematycznych.

W zasadzie przedmiotem zainteresowania niemal wszystkich autorów jest współczesny język mieszkańców miasta, ale w tomie nie mogło też zabraknąć tła historycznojęzykowego i dialektologicznego. W roli kontekstu historycznego występuje filologiczny tekst Magdaleny Czachorowskiej, która nie tylko przypomina postać wybitnego mieszkańca Bydgoszczy - Wojciecha Łochowskiego, w jednej osobie burmistrza i autora jedynej kroniki miasta, ale też szkicowo charakteryzuje grafię i wybraną leksykę siedemnastowiecznego zabytku. W syntetycznie przedstawiony pejzaż dialektalny tworzony głownie przez gwary Borów Tucholskich, ale i inne dialekty Pomorza, wpisuje mowę bydgoszczan Maria Pająkowska-Kensik.

Dwa kolejne teksty traktują, choć z różnej perspektywy i w odmiennych ujęciach o bydgoskich regionalizmach i dialektyzmach miejskich. Łączy je to, że podstawę materiałową stanowi w obu wypadkach historyczny już materiał słownikowy, bo zaczerpnięty $\mathrm{z}$ „sagi o bydgoskim drobnomieszczaństwie" Jerzego Sulimy-Kamińskiego zatytułowanej Most Królowej Jadwigi.

I tak, Andrzej Dyszak omawia w planie geograficznym i formalno-semantycznym germanizmy leksykalne występujące $\mathrm{w}$ mowie mieszkańców Bydgoszczy, dostrzegając w materiale zrozumiałą dominacje zapożyczeń właściwych i tylko śladowy udział replik strukturalnych (z niewiadomych przyczyn pomija kalki semantyczne), a także podkreślając fakt, że wiele z przedstawianych germanizmów ma współcześnie charakter przestarzały lub nawet archaiczny i nie jest notowana $\mathrm{w}$ dzisiejszym języku miasta.

Małgorzata Święcicka natomiast na podstawie rozległych badań ankietowych poddaje drobiazgowemu oglądowi słownikowe regionalizmy zachowane do chwili obecnej w mowie bydgoszczan. Analizuje zwłaszcza różnorodny sposób ich definiowania, czyli rozumienia przez najmłodszych mieszkańców miasta, upatrując w zarejestrowanych błędach słabej znajomości lokalnych właściwości językowych, szczególnie tych, które przynależą do dawniejszych warstw języka. 
Najbardziej rozbudowaną część książki tworzą artykuły o problematyce onomastycznej. Na tle interesująco poprowadzonych rozważań nad współczesnymi chrematonimami oraz historycznym i dzisiejszym nazewnictwem miejskim uderza jednak marginalne potratowanie nazewnictwa osobowego (obecnego $\mathrm{w}$ śladowym wymiarze $\mathrm{w}$ artykule M. Czaplickiej).

Michał Moch i Zofia Sawaniewska-Mochowa przedstawiają bogaty zbiór bydgoskich chrematonimów, analizują ich budową i pochodzenie, rozpatrując w kontekście najnowszych tendencji ogólnopolskich. $W$ uwagach normatywnych na temat budowy i charakteru omawianych nazw, autorzy z ubolewaniem podkreślają liczne wpływy angloamerykańskie zarówno w strukturze, jak i materiale wykorzystanym do kompozycji nazw, ponad to chaos ortograficzny i brak troski o estetyczny wymiar tworzonych chrematonimów.

Do tego tonu nawiązuje w pewnym zakresie Łucja Maria Szewczyk, która przedmiotem swych rozważań czyni regionalne nazwy aptek. $Z$ analizy ich budowy i źródeł wynika, że zmagają się tu dwie tendencje, tradycyjna przejawiająca się $w$ nazwach analitycznych typu: Pod Złotym Orłem, Pod Krzyżem oraz nowsza wprowadzająca do polskiego nazewnictwa formacje, niezbyt szczęśliwie zwane skrótowcami - nazwodawcami, w rodzaju: Chirofarm, Farmamed (s. 153).

Spośród obfitego bydgoskiego nazewnictwa miejskiego (w roku 2001 rejestr urbanonimów obejmuje 1394 jednostki, s. 128) przedmiotem swojego zainteresowania uczyniła Małgorzata Jaracz ciekawą kategorię ponad pięćdziesięciu nazw sakralnych. Do analizowanej klasy nazw autorka zaliczyła nie tylko toponimy bezpośrednio związane ze sferą sacrum, ale i takie, które odnoszą się do niej pośrednio, czyli „(dotyczą) różnych przejawów działalności Kościoła oraz form upamiętniania kultu religijnego i osób z nim związanych" (s. 126), wychodząc z udokumentowanego przez siebie założenia, że w szczególny sposób świadczą one o cywilizacyjnym rozwoju miasta, wypełniając jego duchową i kulturową przestrzeń.

Ogląd miejskiego nazewnictwa Bydgoszczy w planie historycznym przedstawia artykuł Magdaleny Czachorowskiej i Anny Paluszak-Bronka. Autorki zwróciły uwagę na, bardzo interesujące z punktu widzenia losów miasta, a zwłaszcza dwóch epok zarządu niemieckiego 
w okresie zaborów oraz w czasie II wojny światowej, zagadnienie polityki władz okupacyjnych wobec polskich urbanonimów, oraz - będącą jej rezultatem - różnopostaciową (ortograficzno-fonetyczną, morfologiczną, leksykalną) germanizację nazw bydgoskich ulic.

Część onomastyczną zamyka artykuł Marii Czaplickiej, która odtwarza przedwojenne i wojenne nazewnictwo miejskie Bydgoszczy na podstawie materiału antroponimicznego i toponimicznego zawartego w częściowo autobiograficznej powieści Tadeusza Nowakowskiego Obóz Wszystkich Świętych. Analiza językoznawczo-onomastyczna 750 autentycznych i nieautentycznych nazw własnych pozwoliła autorce nie tylko na określenie licznych funkcji, jakie te nazwy pełnią $w$ utworze (lokalizująca, aluzyjna, ekspresywna, aksjologiczna, treściowa, socjologiczna), ale i uchwycenie pewnej części cech dawnej polszczyzny bydgoskiej.

Dwa kolejne rozdziały omawianej książki: $O$ języku bydgoskiej młodzieży i Język wypowiedzi publicznych zawierają teksty poświęcone wyłącznie współczesnej polszczyźnie miasta.

Wiesław Czachowski poddaje wnikliwej analizie bogaty materiał słownikowy i frazeologiczny, zebrany drogą ankietową w lokalnych szkołach średnich, w celu scharakteryzowania miejsca i roli tabu językowego w wypowiedziach bydgoskiej młodzieży. Wypływające $z$ tej analizy wnioski dowodzą powszechnego zainteresowania tematami tabu, zwłaszcza seksem i używkami, przy niemal nieobecnych dziedzinach tabu pierwotnego, jak śmierć i choroba. Uderza zarazem ograniczony charakter stosowanej przez młodzież autocenzury, którą w roli nakazu normatywnego zastępuje pragmatyzm. Skutkuje on na przykład wyraźnie mniejszym nasyceniem wypowiedzi oficjalnych powszechnymi w kontaktach nieoficjalnych wulgaryzmami.

Grażyna Sawicka omawia, znany z innych wielkich polskich miast fenomen tzw. vlepki - mniejszej lub większej karteczki zapełnionej różnorodnymi tekstami, przyklejanej w rożnych miejscach miasta, na murach budynków, szybach autobusów i tramwajów, w przejściach podziemnych itp. Widząc we vlepkach naturalnego kontynuatora tradycji miejskiego graffiti, dowodzi - na drodze analizy struktury tekstów vlepek, wykorzystujących głównie frazeologizmy, frazemy i paremia, oraz 
odbijających świat przez pryzmat ksenofobii i etnocentryzmu - istnienia bydgoskiej subkultury vlepkarzy i jej przynależności do ogólnopolskiego nurtu.

Ewa Korzeniowska i Agnieszka Rypel analizując bogaty materiał leksykalny, ponad pięciu tysięcy jednostek, zebrany drogą ankietową wśród bydgoskich uczniów szkół średnich, dostrzegają w młodzieżowym slangu nie tylko obecność wielu zjawisk i tendencji charakterystycznych dla współczesnej polszczyzny ogólnej (anglicyzacja, wulgaryzacja, prymat odwołań do kultury popularnej), ale upatrują w tym przemożnego wpływu mediów masowych ${ }^{2}$. Przekonują zarazem, że uwzględnienie $\mathrm{w}$ dydaktyce szkolnej zagadnień uczniowskiego socjolektu jest gwarantem lepszych efektów uczenia i wychowania.

Dwa ostatnie artykuły opatruje tytuł: $W$ kręgu wypowiedzi publicz$n e j$. Autorka pierwszego, Iwona Benenowska dokonuje dość wstępnego rozeznania kształtu i treści ponad dwóch tysięcy nagłówków wyekscerpowanych z edycji 2001 lokalnego pomorskiego dziennika, czyli „Gazety Pomorskiej" i dochodzi do przekonania, że sposób wykorzystania w nim składniowych i leksykalnych środków językowych mieści się w ramach ogólnopolskiego standardu językowego i stylistycznego.

Elżbieta Laskowska z kolei poddała analizie wypowiedzi, które pojawiły się podczas posiedzeń Rady Miejskiej Bydgoszczy w pierwszej połowie lat 90 . Wychodząc od opisu środków wartościujących i zabiegów perswazyjnych, poprzez zasady funkcjonowania etykiety językowej i poprawności politycznej, autorka przechodzi do przedstawienia interesujących relacji, jakie zachodzą między językowymi wykładnikami życzliwości i agresji.

Prekursorska próba syntetycznego ujęcia mowy mieszkańców Bydgoszczy, choć w wyborze, który - co przyznaje Małgorzata Święcicka - nie pozwala rościć sobie prawa do miana całościowego oglądu, zasługuje jednak na baczną i życzliwą uwagę. $\mathrm{Z}$ jednej strony jest bowiem podsumowaniem dotychczasowych, aczkolwiek niezbyt licznych i raczej przyczynkarskich badań nad językiem bydgoszczan. $Z$ drugiej,

2 Co znajduje rozległe potwierdzenie w materiale onomastycznym. Por. B. Nowowiejski, Inspiracje kulturowe ruspótczesnych przezzisk uczniowskich na Podlasiu, „Białostockie Archiwum Językowe” 3, 2003, s. 161. 
o czym świadczą liczne napomknienia autorów zebranych tu tekstów, otwiera i zapowiada dalsze, bardziej systematyczne i dogłębne prace badawcze nad językiem Bydgoszczy.

Postulatywny i perspektywiczny charakter tomu wiąże się zapewne $z$ odradzającym się powoli w polskim środowisku językoznawczym zainteresowaniem językiem polskich miast. Po okresie, głównie w latach 70. i 80., intensywnych badań nad polszczyzną wielu polskich ośrodków miejskich, wielkich aglomeracji, ale też małych miast i miasteczek, nastąpiło bowiem swoiste porzucenie tej problematyki. Jej powrotu na lingwistyczne salony może dowodzić metodologiczna konferencja zorganizowana w Białymstoku ${ }^{3}$, zapoczątkowująca także systematyczne badania języka białostoczan, i recenzowany właśnie tom bydgoski.

Całość, mimo pozornego metodologicznego i merytorycznego chaosu, robi dobre wrażenie, książka jest przemyślana, ciekawie skomponowana, przystępna w warstwie merytorycznej i stylistycznej. Powierzchowne potraktowanie części zagadnień da się usprawiedliwić prekursorskim charakterem opracowania, potrzebą przybliżenia lokalnej problematyki czytelnikowi z zewnątrz, adresowaniem książki do językoznawców, ale i zwykłych czytelników, zwłaszcza mieszkańców Bydgoszczy zainteresowanych przeszłością i teraźniejszością własnego języka.

Polszczyzna bydgoszczan to na razie książka głównie obiecująca, jednak jej charakter każe wybaczyć autorom wszelkie niedociągnięcia i mieć nadzieję na poprawę w zapowiadanych kontynuacjach.

Bogusław Nowowiejski

3 Polszczyzna mórviona mieszkańcóv miast. Księga referatóvv z konferencji językoznazvczej w Bialymstoku, red. H. Sędziak, Białystok 2004. 